\title{
PERANAN HEART RATE TERHADAP KUALITAS CITRA PENGGUNAAN “COVID-19” WINDOW UNTUK PEMERIKSAAN CT-SCAN THORAX POLOS PADA PASIEN SUSPEK COVID-19
}

\author{
${ }^{1}$ Anisa Mayasari \\ ${ }^{1}$ Department of Radiology Panti Waluyo Hospital of Surakarta \\ Corresponding author: Anisa Mayasari \\ Email: Crustabitha@gmail.com
}

\begin{abstract}
Background: Non-contrast chest CT-Scan is one of the COVID-19 screening methods. At Panti Waluyo hospital of Surakarta, Non-contrast chest CT-Scan did not use the HRCT technique, low-dose technique, Lung Window, and Mediastinum Window, but used a standard-dose technique and "COVID-19" window.

Methods: The research was conducted at Panti Waluyo hospital of Surakarta, scanning process using GE Brightspeed 8 Slices CT-Scan. The position of the patient is supine feet first, the midline is at the midsagittal plane and axillary line, the scanning process begins with a vertical and horizontal scout photo, scanning area from Thoracal $1^{\text {st }}$ to lumbar $3^{\text {rd }}$, using a helical scan, and "COVID-19" window with $120 \mathrm{kV}, 100 \mathrm{~mA}, 0.8 \mathrm{~s}, 5 \mathrm{~mm}$ slice thickness, FoV $34 \mathrm{~cm}$, gantry tilt $0^{\circ}$, reconstruction $1.25 \mathrm{~mm}$, pitch $1.35: 1$, window width 1600 , and window level -250 .
\end{abstract}

Results: The expertise of Radiologists indicates bilateral pneumonia (typical COVID-19). The "COVID-19" window presents GGO and clarifies the difference between GGO and lung consolidation. It shows the contour of the heart and part of the liver, without adding another window. So, it can increase the effectiveness of time and radiological film.

Conclusions: For non-contrast chest CT-scan in patients with suspected COVID-19, it is better to use the "COVID19 " window than the lung or mediastinal window.

Keywords: Chest CT-Scan; Radiology; COVID-19

\section{Pendahuluan}

Pada masa pandemi COVID-19, radiologi merupakan unit penunjang yang berperan sangat besar dalam screening COVID-19 pada pasien probable, suspek, maupun untuk evaluasi pada pasien confirmed atau yang sudah positif COVID-19. Coronavirus Disease (COVID-19) sendiri adalah penyakit yang disebabkan oleh virus Severe Acute Respiratory Syndrome Coronavirus-2 (SARS-CoV-2) dengan manifestasi klinis yang sangat luas, mulai dari tanpa gejala (Asimptomatik), gejala ringan, pneumonia, pneumonia berat, Acute Respiratory Distress Syndrome (ARDS), sepsis, hingga syok sepsis. ${ }^{9}$

Berdasarkan situs resmi COVID19.go.id, saat ini kasus COVID-19 di Indonesia per tanggal 2 Oktober 2020 telah mencapai 295.499 positif, 221.340 pasien sembuh, dan 10.972 pasien meninggal. Agar jumlah penularan COVID-19 menurun, maka diperlukan dilakukan screening awal sebelum hasil reverse- transcriptase polymerase chain reaction (RT-PCR) jadi, untuk mengetahui apakah pasien tersebut terinfeksi COVID-19 atau tidak.

Ada beberapa metode untuk screening COVID-19 pada pasien, salah satunya adalah CT-Scan Thorax polos atau tanpa kontras, dimana hasilnya lebih cepat dan lebih akurat ${ }^{8,11}$ dengan tingkat sensitivitas lebih besar (98\%) dibandingkan dengan RT-PCR ${ }^{3}$, dan bisa lebih menampakkan Ground Glass Opacity (GGO) yang merupakan gambaran khas COVID-194 dibandingkan foto thorax konvensional ${ }^{12}$.

Menurut Hui Dai et al, penggunaan teknik High Resolution Computed - Tomography (HRCT) untuk pemeriksaan CT-Scan thorax pada pasien COVID-19 menunjukkan penyebaran, bentuk, atenuasi, dan perluasan lesi paru. Disisi lain, menurut Tabatabaei Seyed, et al, dengan menggunakan teknik low-dose dapat menampakkan gambaran kelainan pada CT-Scan Thorax pasien COVID-19 dengan mengurangi dosis 
yang diterima pasien, sehingga dapat mengurangi resiko kanker.

Pemeriksaan CT-Scan thorax polos di Di RS. Panti Waluyo Surakarta, pada pasien suspek COVID-19 tidak memakai teknik HRCT dan Low-dose, serta tidak menggunakan Lung Window maupun Mediastinum Window, tetapi memakai standard dose dan memakai "COVID-19" window yaitu CT-Scan thorax polos biasa dengan ada beberapa parameter yang diubah agar gambaran GGO dan konsolidasi paru lebih jelas dan pemeriksaan menjadi lebih efisien.

\section{Metode}

Metode yang digunakan adalah study kasus, dilakukan di Di RS. Panti Waluyo Surakarta menggunakan CTScan GE Brightspeed 8 Slices, dilakukan registrasi pasien atas nama Ny. Ds pengan klinis suspek COVID19, persiapan pasien dengan memastikan bahwa pasien melepas benda yang dapat mengganggu gambaran, pasien tetap memakai masker persiapan petugas dengan menggunakan Alat Pelindung Diri standar level 3. ${ }^{7}$

Pasien diposisikan pada meja pemeriksaan dengan posisi supine feet first, garis tengah tepat berada pada MSP (Mid Sagital Plane) pasien dan axillary line, batas atas setinggi bahu pasien atau jugular notch, kemudian pasien diinstruksikan unntuk mengikuti aba-aba tarik nafas. Scanning dimulai dengan scout foto posisi vertical dan horizontal, kemudian dilakukan scanning dengan batas atas Thoracal 1 dan batas bawah lumbal 3 dan menggunakan helical scan dan "COVID-19" window dengan parameter sebagai berikut :

Tabel 1. Parameter "COVID-19" window pada CT-Scan Thorax polos

\begin{tabular}{llc}
\hline No & \multicolumn{2}{c}{ Parameter CT-Scan Thorax Polos } \\
\hline 1 & $\mathrm{kV}$ & $120 \mathrm{kV}$ \\
\hline 2 & $\mathrm{~mA}$ & $151 \mathrm{~mA}$ \\
\hline 3 & $\mathrm{~s}$ & $0,8 \mathrm{~s}$ \\
\hline 4 & Slice Thickness & $5 \mathrm{~mm}$ \\
\hline 5 & FoV (Field of View) & $34 \mathrm{~cm}$ \\
\hline 6 & Gantry Tilt & $0^{\circ}$ \\
\hline 7 & Rekonstruksi & $1,25 \mathrm{~mm}$ \\
\hline 8 & Pitch & $1,35: 1$ \\
\hline 9 & Window Width & 1600 \\
\hline 10 & Window Level & -250 \\
\hline
\end{tabular}

Setelah proses scanning selesai, dilakukan reformat image menjadi potongan axial, coronal, dan sagital dengan slice thickness 1,25 $\mathrm{mm}$. Image dicetak dengan menggunakan 1 film radiologi ukuran 14 x 17 inch. Tidak lupa melakukan General Cleanning pada ruang CT-Scan setelah pemeriksaan selesai

\section{Hasil dan Pembahasan}

Gambaran CT-Scan Thorax polos adalah sebagai berikut :

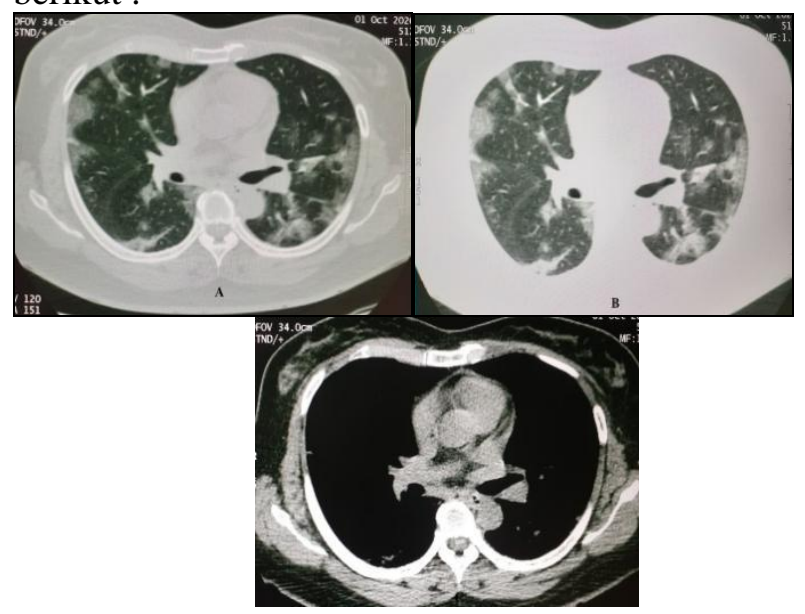

Gambar 1. Potongan axial pada CT-Scan Thorax polos. “COVID-19" window (a). Lung window (b). Mediastinum window (c)

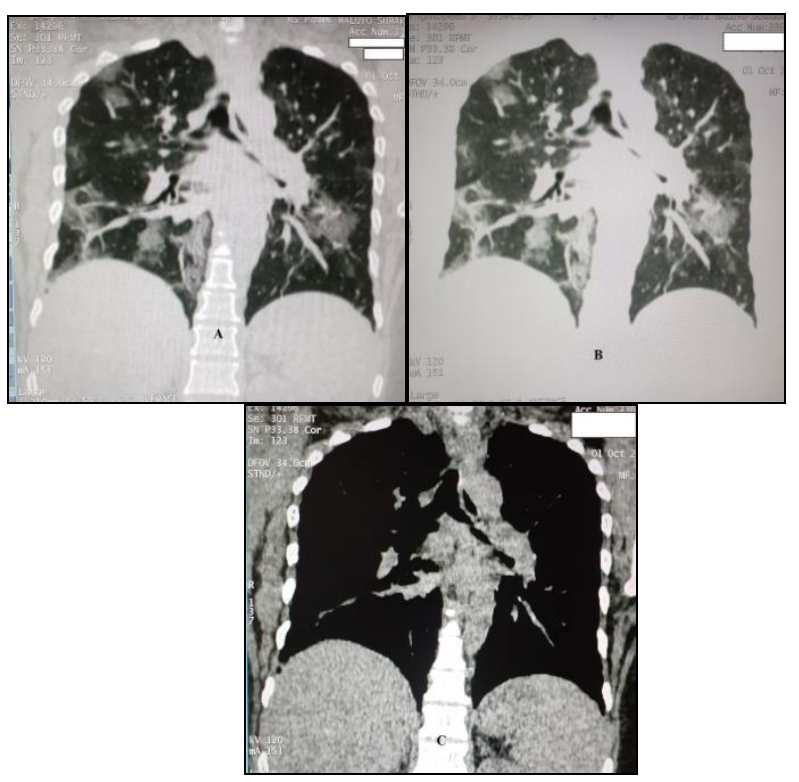

Gambar 2. Potongan coronal pada CT-Scan Thorax polos. “COVID-19” window (a). Lung window (b). Mediastinum window $(\mathrm{c})$ 


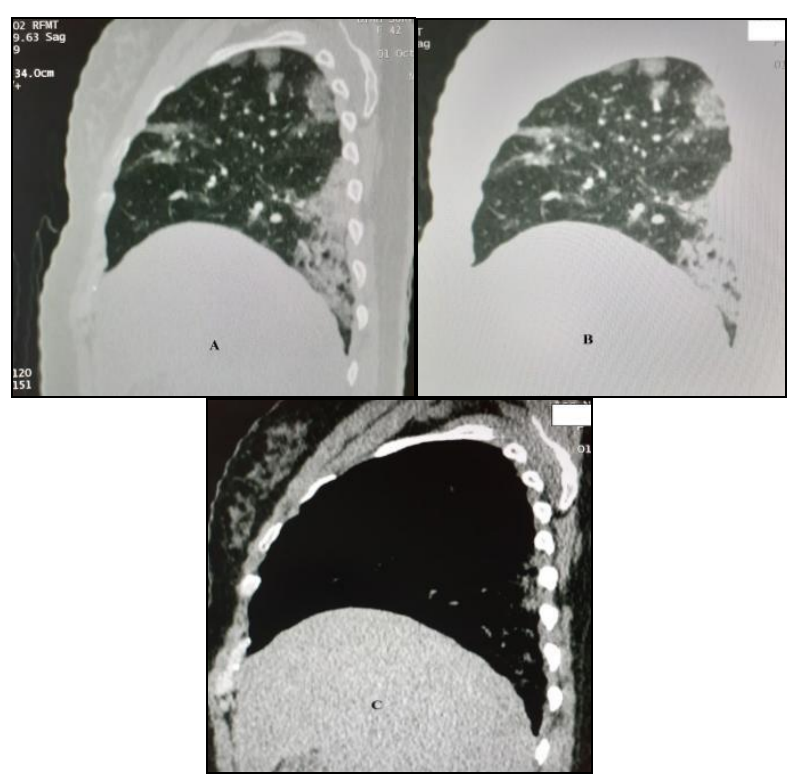

Gambar 3. Potongan sagital pada CT-Scan Thorax polos. “COVID-19" window (a). Lung window (b). Mediastinum window (c)

Hasil bacaan dari dokter spesialis radiologi senior di RS. Panti Waluyo Surakarta pada CT-Scan thorax tanpa kontras atas nama $\mathrm{Ny}$. Ds adalah sebagai berikut : gambaran hemithorax kanan kiri simetris, trachea ditengah, lumen tak menyempit. Corakan bronchovaskuler pada paru kanan-kiri meningkat. Tampak ground glass opasitas luas multifocal perifer bilateral memenuhi kedua lapangan paru. Bronchus utama kanan kiri baik, tak tampak penyempitan lumen, massa dan pembesaran kelenjar limfe pada mediastinum sulit untuk dievaluasi. Tak tampak effusi pleura maupun asites. Posisi dan kontur diafragma normal. Tak tampak destrusi tulang pada thoracic skeleton, thoracic soft tissue terlihat simetris dan densitasnya normal. Tak tampak nodul pada sebagian hepar yang terlihat. Tak tampak pembesaran kelenjar suprarenal.

Disimpulkan bahwa berdasarkan gambaran CTScan thorax polos tersebut cenderung kearah gambaran pneumonia bilateral (typical COVID-19).

Pada proses scanning thorax polos dengan menggunakan "COVID-19" window, tetap menggunakan slice thickness $5 \mathrm{~mm}$, karena jika menggunakan slice thickness $1,25 \mathrm{~mm}$ maka noise akan semakin besar dan dosis radiasi yang diterima pasien juga akan semakin besar ${ }^{1}$. Untuk mengatasi hal tersebut, maka dapat dilakukan reformat setelah scanning selesai dengan mengubah slice thickness menjadi $1,25 \mathrm{~mm}$. Dengan memperkecil slice thickness pada saat reformat, maka akan menghasilkan gambaran akan lebih detail sehingga dapat menampakkan gambaran GGO dengan lebih jelas. Dengan mengatur window width 1600 dan window level -250, lebih bisa menampakkan GGO dan dapat memperjelas perbedaan antara GGO dengan konsolidasi paru. Selain itu dapat menampakkan kontur jantung,dan sebagian hepar yang terlihat, tanpa harus menambahkan window yang lain.

selain RT-PCR dan foto thorax konvensional, CTScan thorax polos dapat melengkapi sekaligus mengkonfirmasi diagnosa pada pasien COVID-19. Hal ini berguna untuk tenaga medis agar tidak salah dalam menentukan status pasien suspek COVID-19, sehingga tingkat penularan COVID-19 di Indonesia bisa menurun.

Selain itu, dengan menggunakan "COVID-19" window pada CT-Scan thorax polos dapat meningkatkan efektifitas waktu dalam pencetakan film karena hanya memakai 1 window saja, sehingga dapat mempercepat penegakan diagnosa pada pasien suspek COVID-19. Selain itu, dengan menggunakan "COVID-19" window dapat menekan pengeluaran barang habis pakai yaitu film radiologi.

\section{Simpulan}

Untuk pemeriksaan CT-Scan Thorax polos pada pasien suspek COVID-19 lebih baik menggunakan "COVID-19" window dibandingkan dengan lung window maupun mediastinum window, karena dapat menampakkan gambaran GGO dengan lebih jelas sehingga pemeriksaan menjadi lebih efektif.

\section{Daftar Pustaka}

1.Alshipli, M., Kabir, N.A. Effect of Slice thickness on image noise and diagnostic content of single-source-dual energy computed tomography. IOP Conf. Series Journal of Physics, 2017, 851012005.

2.Dai, H., Zhang, X., Xia, J., Zhang, Tao., Shang, Y., Huang, R., Liu, R., Wang, D., Li, M., Wu, J., Xu, Q., Li, Y. High-resolutin Chest CT Features and Clinical Charactetristics of Patients Infected with COVID-19 in Jiangsu, China. International Journal of Infectious Diseases 95, April 2020, 106-112.

3.Fang, Y., Zhang, H., Xie, J, Lin, M., Ying, L., Pang, P., ji, W. Sensitifity of Chest CT for COVID-19: Comparison to RT-PCR. Radiology, Agustus 2020, 296:E115E117.

4.Handayani, D., Hadi, D.R., Isbaniah, F., Burhan, E., Agustin, H. Penyakit Virus Corona 2019. Jurnal Respirologi Indonesia, April 2020, Vol. 40 No. 2.

5.Hani, C., Trieu, N.H., Saab,I. Dangeard, S., Bennani, S., Chassagnon, G., Revel, M.-P. COVID-19 pneumonia : $A$ review of typical $C T$ findings and differential diagnosis. Diagnostic and Intervensional Imaging 101 2020, 263-268. 
6.Komite penanganan COVID-19 dan pemulihan ekonomi nasional. Data Sebaran Indonesia. Diakses pada tanggal 2 oktober 2020, 7:43 pm. https://COVID19.go.id.

7.Komite penanganan COVID-19 dan pemulihan ekonomi nasional. Rekomendasi Standar Pengggunnaan APD untuk Penanganan COVID-19 di Indonesia Revisi 1. Diakses pada tanggal 9 oktober 2020, 9:30 am. https://COVID19.go.id/p/protokol/rekomendasistandar-penanganan-COVID-19-di-indonesia-revisi-1.

8.Restuningdyah, N., Amalia, E. Pemeriksaan CT-Scan Thorax pada Kasus COVID-19 di Provinsi Nusa Tenggara Barat. Jurnal Pengabdian Magister Pendidikan IPA. (3) 1 , 2020, 34-37: e-ISSN:26555263.

9.Susilo, A., Rumende, C. M., Pitoyo, C. W., Santoso, W. D., Yulianti, M., Herikurniawan, H., ... Yuniastuti, E. Coronavirus Disease 2019: Tinjauan Literatur Terkini. Jurnal Penyakit Dalam Indonesia, April 2020, 7(1) 45 .

10.Tabatabaei, S.M.H., Talari, H., Gholamrezanezhad, A., Farhood, B., Rahimi, H., Razzaghi, R., Mehri, N., A Low-dose Chest CT protocol for the diagnosis of COVID-19 pneumonia: a prospective study. American Society of Emergency Radiologi. Agustus 2020

11.Tenda, E D., Yulianti, M., Asaf, M.M., Yunus, R. E., ... Setiati, S., The Importance of Chest CT-Scan in COVID-19 : A Case Series. Acta Med Indones-Indones J Intern Med, Jan 2020, Vol. 52 No. 1.

12.Zhang, S., Li, H., Huang, S., You, W., Sun, H. Highresolution computed tomography features of 17 cases of coronavirus disease 2019 in Sichuan province, China. Eur Respir J, Feb 2020, 55: 20003 